\title{
Screening Variables in Reducing the Brown Color from the Filtrate of Heavy Metal's Elimination
}

\author{
Indrajati Kohar', Soediatmoko Soediman'1, Mario', Deby Vinolia', Ni Nyoman Tri Puspaningsih², and \\ Leon Janssen ${ }^{3}$
}

${ }^{1}$ Laboratory of Pharmaceutical Chemistry, Faculty of Pharmacy, University of Surabaya, Indonesia
${ }^{2}$ Faculty of Sains and Technology, University of Airlangga, Indonesia
${ }^{3}$ Department of Chemical Engineering, Faculty of Science, Rijks Universiteit of Groningen, The Netherlands

Korespondensi: Indrajati Kohar

Email: indrakohar@yahoo.com

\begin{abstract}
Heavy metals contamination is a major concern in the world, and also is in Indonesia. Many attempts have been done to reduce or even eliminate it from the environment, among other ways the use of agriculture waste, such as rice straw. Why use rice straw? Because it is available abundantly. Many studies showed that rice straw could adsorb heavy metals from polluted water, and it is cheap. The drawback of rice straw is the color of the filtrate is brown, so that it cannot be used for everyday or household purposes. An attempt using enzyme has been tried to reduce the brown color and it did reduce the brown color. Enzyme L- $\alpha$-arabino-furanosidase is used in this study. However, as there are many variables used in the experiments, before optimization can be conducted, a screening needs to be carried out first. Type of enzyme (optimum temperature of $50^{\circ} \mathrm{C}$ and $70^{\circ} \mathrm{C}$ ), incubation time and amount of enzyme, number time of washing, water for washing, place of the rice plantation (high land and low land), and size of straw, are the variables that need to be screened. The variables that gives the highest response in this study were enzyme-50, amount of enzyme : straw $=2: 1$ (10 ml of enzyme for each 5 $g$ of straw), 1 hour incubation time, amount of washing : $5 \times 5 \mathrm{ml}$, place of plant: low land, and size of straw: ground. As for the type of washing liquid, both either demineralised water or Pb solution were the same. However, the variables are still need to be reduced, and the experiment/study will be continued to optimize the reduced variables.
\end{abstract}

Keywords: brown color; rice straw filtrate; heavy metals; L- $\alpha$-arabino-furanosidase 


\section{Introduction}

Heavy metals contamination of ground and surface water is of growing concern in many parts of the world, particularly in developing countries in which large populations have to use these sources for drinking and cooking water. Indonesia is facing substantial heavy metal pollution of ground and surface water in industrialized areas. A study by Sutomo et al. [1] found that there was $\mathrm{Pb}$ in drinking water in an area in Yogyakarta and its impact on children. Yuliandari et al. [2] reported that the blood samples of pregnant women, breast feeding mothers and children under five years old in Kenjeran area (in Surabaya) contained heavy metals such as $\mathrm{Cd}, \mathrm{Hg}$, and $\mathrm{Pb}$. Kohar et al. [3] in their study on the hair of autistic and non autistic children and adults also found an interesting results, that the hair of the autistic children contained twice as much lead as the hair of non autistic adults, and the adults hair also contained twice as much lead as in the hair of non autistic children. Joel Nigg of Oregon Health \& Science University in Portland points to lead as an ideal candidate to trigger the developmental disorder called ADHD. In his article, published in Current Directions in Psychological Science, Nigg offers a causal model in which lead attaches to sites in the brain's striatum and frontal cortex, and acts on the genes in these regions causing them to turn on or remain inactive. This disruption in brain activity alters cognitive control, and in turn results in hyperactivity and lack of vigilance.

Many studies have been conducted to eliminate heavy metals from water resources, such as flocculation, filtration, using activated charcoal, and ion exchange, precipitation by chemicals, etc. However, because of the high cost of these methods, the development of a more cost-effective and environmental friendly remediation system is necessary [4]. In order to find more cost-effective and environmental friendly methods, several studies have been carried out, by using living and dried plants, and agricultural wastes, such as soybean hulls, sugarcane bagasse, rice hulls, rice straw, barley straw, rice milling by product, etc., treated or untreated [5-16].

On the other hand, Indonesia also has vast number of padi fields, and the production of rice is over 50 million tons per year, and the resulting rice straw is considered agricultural waste that is usually burnt in the fields, thus yielding a lot of smog. Yet, rice straw has not received much attention as a potential remover of heavy metals so far, and the results appear to be inconclusive. Kumar and Dara [6] compared rice straw and rice husk with sugar cane bagasse, onion skin and garlic skin and found onion skin to be the best adsorption material. Marshall et al. [9] found the adsorption capacity of rice straw for $\mathrm{Zn}$ to be lower than that of soybean hulls and cottonseed hulls, but higher than that of sugar cane bagasse. Larsen and Schierup [7] used three types of barley straw (Hordeum vulgare): (1) dried and ground in a mill, referred to as straw (untreated); (2) dried, ground, boiled, and washed three times in demineralized water, referred to as straw (washed); (3) treated as in (2) and mixed with pulverized $\mathrm{CaCO}_{3}(2: 1)$, referred as straw (washed) $+\mathrm{CaCO}_{3}$. Other authors proposed soaking in 3-8\% $\mathrm{NaOH}$ solutions [6, 9, 12, 17]. It has been postulated that water treatment and alkali treatment will remove lignin and hemicelluloses, respectively, thus making the adsorptive sites more easily and abundantly available. Another issue when using plant material or agricultural waste for heavy metal adsorption is whether to use the materials as is, or to first subject them to modification by chemical treatment. Kohar and de Zeeuw, and their co workers [18] found that rice straw as is adsorbed $\mathrm{Cd}(\mathrm{II})$ and $\mathrm{Pb}(\mathrm{II})$ from aqueous solution substantially higher than that of activated carbon and no chemical pretreatment of the straw was necessary to yield optimum results.

The particle size experiment show that at lower concentration of $\mathrm{Pb}(\mathrm{II})$ in terms of $\mathrm{mg} \mathrm{Pb}$ adsorbed/g straw the differences between particle sizes are less significant, and there is an optimum in the amount of $\mathrm{Pb}$ adsorption by straw. 
The influence of particle size of straw can be detected only at higher initial concentration of $\mathrm{Pb}$ solution [19].

Although straw has been a good adsorbent for heavy metals in solution there is a drawback in using it for cleaning polluted water from heavy metals, which is the brown colour produced when straw is soaked in water. The filtrate has brown colour, and of course it cannot be used in everyday needs not to say as drinking water. Some means and materials have been used to clean the filtrate from the brown colour, such as bentonite, zeolite, sand, charcoal, and carbo adsorbent [20]. Actually carbo adsorbent can be used in laboratory experiment, when nylon was used as the filter. It could adsorb the brown colour, but to filter the carbo adsorbent was another problem. It passes ordinary filter, such as filter paper or cotton cloth, and will give some blackish colour in the water. That was why it cannot be used in large or medium scale, especially for the purpose in a contaminated well in a village, where a large nylon filter will be very costly; so cotton cloth will be more suitable for this purpose.

A preliminary study using $\mathrm{L}$ - $\alpha$-arabino-furanosidase enzyme has been conducted in eliminating the brown colour (which is due to lignin) of the straw's extract, and it showed a satisfactory result, which is extracting lignin from the straw and the end result is clear water with low concentration of heavy metal $(\mathrm{Pb})$. So, it is imperative to continue the research using the enzyme. In this research the optimization of the process will be carried out by varying on the amount of enzyme $(\mathrm{ml})$, time of incubation (h), number of washings, and the type and size of straw. However, due to the many variables which will be optimized, screening of variables will be exercised first.

\section{Materials and methods}

\subsection{Materials}

Two different types of rice straw are investigated: rice straw from highland, i.e. rice which is grown in mountainous areas (Trawas area in Mojokerto) (1) and rice straw from lowland, i.e. rice which is grown at low altitude (collected in Surabaya). Chemicals used were Pb standard solution 1000 ppm (Merck), demineralised water (Ubaya's Chemical Laboratory), $\mathrm{Pb}$ acetate p.a. (Merck), and enzyme L- $\alpha$-arabino-furanosidase (from Tropical Disease Center Laboratory-Airlangga University).

\subsection{Instrumentations}

UV-Vis Spectrophotometer, Inductively Coupled Plasma Spectrometer (Fisons, model 3410+ ARL, Valencia, California-USA, with argon as (reactant) mobile gas), analytical balance, glass wares for laboratories, etc.

\subsection{Experimental design}

Experimental design is used to screen: the type of enzyme used (enzymes with an optimum working temperature of $50^{\circ} \mathrm{C}=$ enzyme- 50 or $70^{\circ} \mathrm{C}=$ enzyme-70) (1); the relative amount of enzyme used (2); the time of incubation of straw with enzyme (3); the number of washings after the enzyme treatment (4); the size of the straw (5); place of plantation (highland and lowland) (6); and the type of water used for washing the straw: demineralised water vs artificial polluted water (7). First step of the experimental design is

Table 1. Details of the codes

\begin{tabular}{llllllll}
\hline Code & $\begin{array}{l}\text { Enzyme } \\
\text { (A) }\end{array}$ & $\begin{array}{l}\text { Incubation } \\
\text { time (B) }\end{array}$ & $\begin{array}{l}\text { Volume of } \\
\text { enzyme (C) } \\
\text { (ml) }\end{array}$ & $\begin{array}{l}\text { Number of } \\
\text { washing } \\
\text { (D) }\end{array}$ & $\begin{array}{l}\text { Location of } \\
\text { straw } \\
\text { (E) }\end{array}$ & $\begin{array}{l}\text { Size of } \\
\text { straw } \\
\text { (F) }\end{array}$ & $\begin{array}{l}\text { Water for } \\
\text { washing } \\
\text { (G) }\end{array}$ \\
\hline-1 & $50^{\circ} \mathrm{C}$ & 1 hour & 10 & 1 & Lowland & Ground & Aq.dem. \\
1 & $70^{\circ} \mathrm{C}$ & 5 hours & 40 & 5 & Highland & $30 \mathrm{~cm}$ & Pb Solution \\
\hline
\end{tabular}


to screen the variables in two replications. Using the Minitab program, an order of the experiment is defined (Table 1).

As output parameter, the following parameters will be used as the responses: the absorbance of the brown colour (the colour can be determined by spectrophotometer, by the absorbance of the brown colour) (1) and \% adsorbed of $\mathrm{Pb}$ (the removal of lead can be determined by ICPS) (2).

\subsection{Protocol of the research}

Metal concentrations are measured by atomicemission spectrometry (AES), using an inducedcoupled-plasma instrument (Fisons, model 3410+ ARL, Valencia, California-USA), with argon as (reactant) mobile gas. The wavelength for $\mathrm{Pb}$ emission is $283.306 \mathrm{~nm}$. Standard curve of $\mathrm{Pb}$ solution: diluting standard solution of $\mathrm{Pb}(1000$ ppm) into several concentrations $(1,2,5,10$, and $15 \mathrm{ppm}) . \mathrm{Pb}$ solutions as sample: dissolving $\mathrm{Pb}$ acetate p.a. and diluting it to make $5 \mathrm{ppm}$ aqueous solution.

\subsection{Pretreating rice straw with enzyme}

Five grams of rice straw (ground, half length or whole length) is wetted with the enzyme (con- centration of straw $(\mathrm{g})$ : enzyme $(\mathrm{ml})=1: 0 ; 1: 4$; $1: 8$; according to the experimental design's run), and is allowed at room temperature at certain times (also in line with the experimental design's run), then washed with 25 ( $5 \times 5)$ ml demineralised water or with artificial $(\mathrm{Pb})$ contaminated water (certain number of times, in line also with the experimental design's run). The filtrate of these washings will show brown colour, and the intensities of the brown colour are measured by visible spectrophotometer to detect the increasing of brown colour with the increasing of the enzyme used.

\subsection{Removal of $\mathrm{Pb}$ (II) by pretreated rice straw}

The remaining rice straw (of 2.5) is then air dried, and is used to adsorb $\mathrm{Pb}(\mathrm{II})$ from solution. Pretreated straw $(0.5 \%)$ is soaked in $\mathrm{Pb}$ (II) solutions for 1 hour, then filtered through a nylon filter (Millipore; $0.45 \mu \mathrm{m}$ - to avoid any adsorbtion of $\mathrm{Pb}$ (II) by filter paper), and the remaining $\mathrm{Pb}$ (II) in the filtrate is determined by ICPS. The $\%$ of $\mathrm{Pb}$ removed from the solution and the mg of $\mathrm{Pb}$ adsorbed/g straw are calculated using equation below. All the data collected were analysed by means of Minitab program.

$$
\begin{aligned}
& \% \text { of } \mathrm{Pb} \text { adsorbed }=\frac{\text { initial conc. }- \text { final conc. }(p p m)}{\text { initial conc. }(p p m)} \times 100 \% \\
& \mathrm{mg} \text { of } \mathrm{Pb} \text { adsorbed } / \mathrm{g} \text { straw }= \\
& \left(\frac{\text { initial conc. }(p p m) x P b \text { solution }(\mathrm{g})}{1000}\right)-\left(\frac{\text { final conc. }(p p m) x \text { filtrate }(\mathrm{g})}{1000}\right) / \text { straw }(\mathrm{g})
\end{aligned}
$$

\section{Results and discussion}

\subsection{Determination of maximum wavelength of} the brown color

Determination of the maximum wavelength of the brown color was carried out by scanning the filtrate of the straw on the UV-VIS Spectrophotometer at 400-600 $\mathrm{nm}$, and it was obtained that the $\lambda_{\text {max }}$ of the brown color of the straw's filtrate was $473 \mathrm{~nm}$.
3.2. Preparation of $P b$ solution's calibration curve

Table 2. Intensities of different concentrations of $\mathrm{Pb}$ solutions

\begin{tabular}{ll}
\hline Concentration (ppm) & Intensities \\
\hline 0 & 0.034 \\
0.5 & 0.043 \\
1 & 0.050 \\
2 & 0.071 \\
5 & 0.122 \\
10 & 0.206 \\
\hline
\end{tabular}




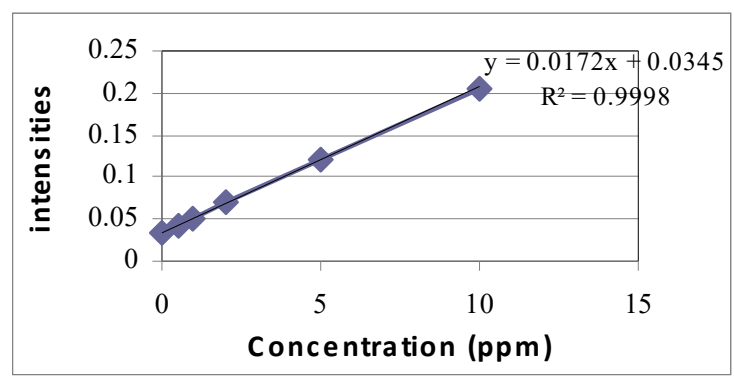

Figure 1. Calibration curve of $\mathrm{Pb}$ solution

\subsection{The activity of the pretreated straw on the adsorption of $\mathrm{Pb}$ (II)}

The results of the treatment of straw with L- $\alpha$ arabino-furanosidase is in Table 3.

\subsection{Minitab data analyses of experiments using $25 \mathrm{ml}$ of washing liquids}

Figure 2. showed that enzyme-70 removed more lignin than enzyme-50; the longer the incubation time ( $5 \mathrm{~h})$, the higher the absorbance; the more enzyme was added, the more lignin was removed; the more the washing, the absorbance was higher; rice straw from highland released more lignin; lignin was removed easier from ground straw; and the absorbance was higher when washed with demineralised water, than with $\mathrm{Pb}$ (II) solution.

Figure 3. explained that when enzyme-50 (black line) and enzyme-70 (red line) were at level -1 (lowland), the $\% \mathrm{~Pb}$ adsorbed by the resulted pretreated straw were about the same i.e. around $45 \%$. When they were at level 1 (highland), the $\% \mathrm{~Pb}$ adsorbed by enzyme-50-pretreated straw was still around $45 \%$, but that of enzyme-70-pretreated straw dropped drastically to around $20 \%$. This phenomenom can be explained, by the fact that the straw from highland was collected after it had remained for sometimes on the rice fields, getting wet from rain and dried under the sun and open air, so the condition was more fragile than the straw form lowland, and because of that it lost its lignin content easier than the straw from low land did. As it was already studied, lignin also has metal-adsorbing activity.

Figure 4. showed that when enzyme-50 (black line) was at point 1 ( $1 \mathrm{x}$ washing), $\% \mathrm{~Pb}$ adsorbed was around $50 \%$, while $\mathrm{Pb}$ adsorbed of enzyme70-pretreated straw (red line) was 25\%. However, when they were at level 5 (5 times washing) the $\% \mathrm{~Pb}$ adsorbed of both pretreated straw were about $40 \%$ and $45 \%$ respectively for enzyme- 70 and enzyme-50-pretreated straw.

Figure 5. also showed that when enzyme-50 and enzyme-70-pretreated straw were obtained by treating it with $10 \mathrm{ml}$ of enzyme, the $\% \mathrm{~Pb}$ adsorbed were $45 \%$ and $40 \%$ respectively. However, when $40 \mathrm{ml}$ of enzyme was used, the $\% \mathrm{~Pb}$ adsorbed were $50 \%$ and $30 \%$ respectively. It also showed that there were a decrease in $\% \mathrm{~Pb}$ adsorbed in line with the increase of the intensity of the brown colour, meaning the more lignin lost it also followed by the decrease in the metal adsorption.

The above graph (Figure 6.) showed that when straw was incubated for 1 hour with either enzyme-50 (black line) or enzyme-70 (red line), the $\% \mathrm{~Pb}$ adsorbed on the resulted pretreated straw were $50 \%$ and $40 \%$ repectively. However, when the incubation time was raise to 5 hours, the $\% \mathrm{~Pb}$ adsorbed became $45 \%$ and $30 \%$ respectively.

Figure 7. showed that when straw was incubated at 1 hour (black line) and at 5 hours (red line), and then was washed once, the $\% \mathrm{~Pb}$ adsorbed of the resulted pretreated straw were $40 \%$ and below $35 \%$ respectively, while when they were washed 5 times, the $\% \mathrm{~Pb}$ adsorbed of both types of the resulted straw were about the same, i.e. around $45 \%$.

Another experiment was also carried out. The amount of the washing liquid of $50 \mathrm{ml}$ was compared to that of $25 \mathrm{ml}$, and analysed by paired $\mathrm{t}$ test. It showed that the results for both treatment was not significantly different. So, for cost saving, $25 \mathrm{ml}$ can be used to wash the straw.

The colour of the filtrate of ground straw tends to be browner than that of half length $( \pm 30 \mathrm{~cm}$ long), however, the $\% \mathrm{~Pb}$ adsorbed relatively higher that that of half length straw, due to the larger surface area of the ground straw. Eventhough the $\% \mathrm{~Pb}$ adsorbed is higher, the half length straw is 
Table 3. Activity of pretreated straw on the adsorption of $\mathrm{Pb}$ (washing with $25 \mathrm{ml}$ of washing liquid)

\begin{tabular}{|c|c|c|c|c|c|c|c|c|c|c|}
\hline No & $\begin{array}{l}\text { T. o.e. } \\
\left({ }^{\circ} \mathrm{C}\right)\end{array}$ & In. t. (h) & $\begin{array}{l}\text { Enzyme } \\
\text { (ml) }\end{array}$ & A. o. w. & Pl. o p. & L. o. str. & W. liq. & $\%$ ads. & Cl. F. & Ads/g \\
\hline 3 & 50 & 5 & 10 & $1 \mathrm{x}$ & DT & $\pm 30 \mathrm{~cm}$ & $\mathrm{Aq}$ & 29.64 & + & 0.30 \\
\hline 8 & 70 & 5 & 40 & $1 \mathrm{x}$ & DT & ground & $\mathrm{Aq}$ & 16.57 & ++ & 0.17 \\
\hline 5 & 50 & 1 & 40 & $1 \mathrm{x}$ & DT & $\pm 30 \mathrm{~cm}$ & $\mathrm{~Pb}$ & 39.98 & ++ & 0.36 \\
\hline 26 & 70 & 1 & 10 & $5 x$ & DT & $\pm 30 \mathrm{~cm}$ & $\mathrm{Aq}$ & 22.16 & ++ & 0.16 \\
\hline 4 & 70 & 5 & 10 & $1 \mathrm{x}$ & DR & $\pm 30 \mathrm{~cm}$ & $\mathrm{~Pb}$ & 20.99 & clear & 0.20 \\
\hline 2 & 70 & 1 & 10 & $1 \mathrm{x}$ & DT & ground & $\mathrm{Pb}$ & 39.54 & ++ & 0.36 \\
\hline 24 & 70 & 5 & 40 & $1 \mathrm{x}$ & DT & ground & $\mathrm{Aq}$ & 17.30 & ++ & 0.19 \\
\hline 9 & 50 & 1 & 10 & $5 x$ & $\mathrm{DR}$ & $\pm 30 \mathrm{~cm}$ & $\mathrm{~Pb}$ & 33.26 & clear & 0.28 \\
\hline 7 & 50 & 5 & 40 & $1 \mathrm{x}$ & $\mathrm{DR}$ & ground & $\mathrm{Pb}$ & 61.30 & + & 0.56 \\
\hline 11 & 50 & 5 & 10 & $5 \mathrm{x}$ & DT & ground & $\mathrm{Pb}$ & 58.37 & + & 0.54 \\
\hline 15 & 50 & 5 & 40 & $5 x$ & DR & $\pm 30 \mathrm{~cm}$ & $\mathrm{Aq}$ & 30.50 & clear & 0.28 \\
\hline 6 & 70 & 1 & 40 & $1 \mathrm{x}$ & $\mathrm{DR}$ & $\pm 30 \mathrm{~cm}$ & $\mathrm{Aq}$ & 28.10 & clear & 0.24 \\
\hline 13 & 50 & 1 & 40 & $5 x$ & DT & ground & $\mathrm{Aq}$ & 61.57 & + & 0.58 \\
\hline 22 & 70 & 1 & 40 & $1 \mathrm{x}$ & $\mathrm{DR}$ & $\pm 30 \mathrm{~cm}$ & $\mathrm{Aq}$ & 24.51 & clear & 0.23 \\
\hline 12 & 70 & 5 & 10 & $5 x$ & $\mathrm{DR}$ & ground & $\mathrm{Aq}$ & 71.39 & ++ & 0.72 \\
\hline 32 & 70 & 5 & 40 & $5 x$ & DT & $\pm 30 \mathrm{~cm}$ & $\mathrm{~Pb}$ & 10.98 & + & 0.11 \\
\hline 28 & 70 & 5 & 10 & $5 x$ & $\mathrm{DR}$ & ground & $\mathrm{Aq}$ & 74.31 & ++ & 0.76 \\
\hline 1 & 50 & 1 & 10 & $1 \mathrm{x}$ & $\mathrm{DR}$ & ground & $\mathrm{Aq}$ & 60.09 & ++ & 0.54 \\
\hline 30 & 70 & 1 & 40 & $5 x$ & $\mathrm{DR}$ & ground & $\mathrm{Pb}$ & 62.41 & + & 0.53 \\
\hline 29 & 50 & 1 & 40 & $5 x$ & DT & ground & $\mathrm{Aq}$ & 61.74 & + & 0.58 \\
\hline 17 & 50 & 1 & 10 & $1 \mathrm{x}$ & $\mathrm{DR}$ & ground & $\mathrm{Aq}$ & 62.56 & ++ & 0.56 \\
\hline 20 & 70 & 5 & 10 & $1 \mathrm{x}$ & $\mathrm{DR}$ & $\pm 30 \mathrm{~cm}$ & $\mathrm{~Pb}$ & 24.02 & clear & 0.22 \\
\hline 23 & 50 & 5 & 40 & $1 \mathrm{x}$ & $\mathrm{DR}$ & ground & $\mathrm{Pb}$ & 64.58 & + & 0.59 \\
\hline 10 & 70 & 1 & 10 & $5 x$ & DT & $\pm 30 \mathrm{~cm}$ & $\mathrm{Aq}$ & 19.84 & ++ & 0.14 \\
\hline 19 & 50 & 5 & 10 & $1 \mathrm{x}$ & DT & $\pm 30 \mathrm{~cm}$ & $\mathrm{Aq}$ & 32.27 & + & 0.34 \\
\hline 18 & 70 & 1 & 10 & $1 \mathrm{x}$ & DT & ground & $\mathrm{Pb}$ & 35.87 & ++ & 0.34 \\
\hline 14 & 70 & 1 & 40 & $5 x$ & $\mathrm{DR}$ & ground & $\mathrm{Pb}$ & 64.39 & + & 0.57 \\
\hline 16 & 70 & 5 & 40 & $5 x$ & DT & $\pm 30 \mathrm{~cm}$ & $\mathrm{~Pb}$ & 12.60 & + & 0.12 \\
\hline 21 & 50 & 1 & 40 & $1 \mathrm{x}$ & $\mathrm{DT}$ & $\pm 30 \mathrm{~cm}$ & $\mathrm{~Pb}$ & 37.98 & ++ & 0.35 \\
\hline 25 & 50 & 1 & 10 & $5 \mathrm{x}$ & $\mathrm{DR}$ & $\pm 30 \mathrm{~cm}$ & $\mathrm{~Pb}$ & 29.37 & clear & 0.24 \\
\hline 31 & 50 & 5 & 40 & $5 \mathrm{x}$ & $\mathrm{DR}$ & $\pm 30 \mathrm{~cm}$ & $\mathrm{Aq}$ & 33.16 & clear & 0.26 \\
\hline 27 & 50 & 5 & 10 & $5 x$ & DT & ground & $\mathrm{Pb}$ & 59.16 & + & 0.54 \\
\hline
\end{tabular}

Note: No = std. order; t.o.e. $=$ type of enzyme; In.t.= incubation time; A.o.w.= amount of washing; Pl.o.p.= place of plant; L.o.str. = length of straw; w.liq.= washing liquid; $\%$ ads. $=\%$ adsorbed; $\mathbf{C l . F}=$ = colour of filtrate; Ads $/ \mathbf{g}=\mathbf{m g}$ of $\mathrm{Pb}$ adsorbed/g straw, $\mathbf{D T}=$ high land; $\mathrm{DR}=$ low land, $\mathbf{A q}=$ demineralised water, $\mathbf{P b}=\mathrm{Pb}$ (II) solution (5 ppm). $+=$ light brown colour $++=$ brown colour

more preferable, as the colour of the filtrate was clearer. To increase the elimination of $\mathrm{Pb}$ from the water, the soaking of process can be repeated several times with new pretreated straw, or by soaking the half length straw with more enzyme, so that more lignin will be removed, and the filtrate will be clearer.
Based on statistical analyses, it can be concluded that the type of enzyme, amount of enzyme: straw, incubation time, number of washings, place of plant, and size of straw posses some effect on the adsorption of heavy metal. Because type of washing liquid did not influence the adsorption process, in other words, the results of 


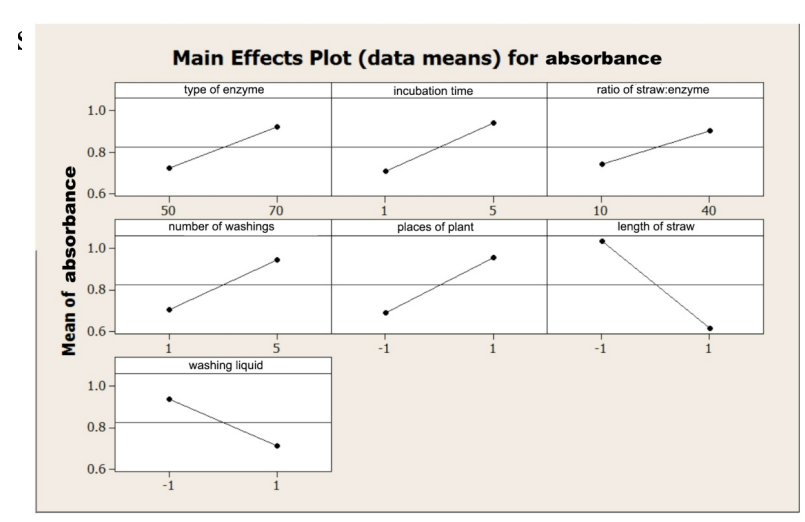

Figure 2. Main effects plot for absorbance

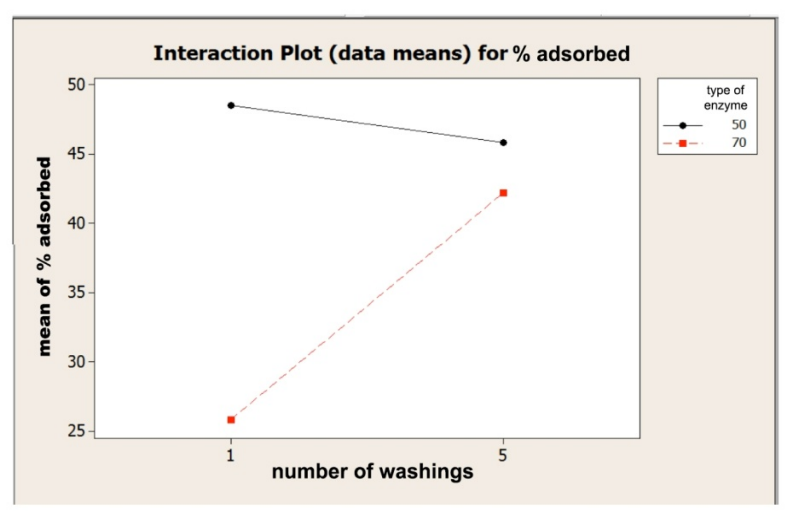

Figure 4. Interaction between types of enzyme vs number of washing

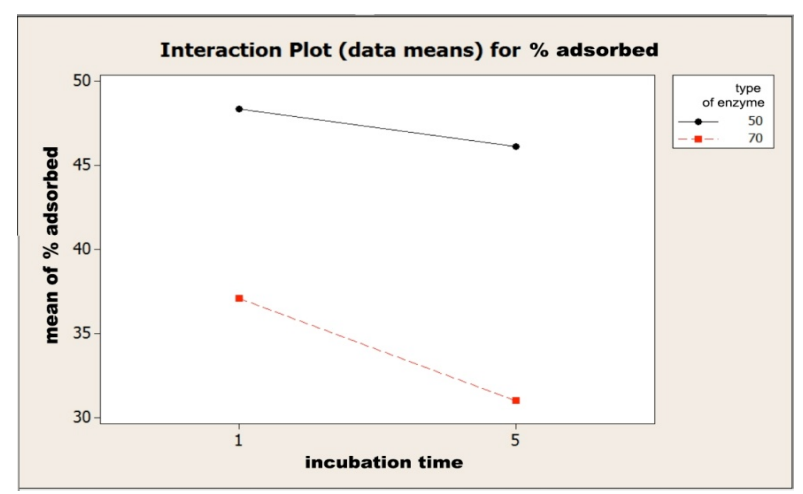

Figure 6. Interaction between types of enzyme vs time of incubation

washing with demineralised water or $\mathrm{Pb}(\mathrm{II})$ solution would be about the same.

The variables that give the highest respond in this case were enzyme-50, amount of enzyme : straw $=2: 1(10 \mathrm{ml}$ of enzyme for each $5 \mathrm{~g}$ of straw), 1 hour incubation time, number of washings: $5 \times 5 \mathrm{ml}$, place of plant: lowland, and size of

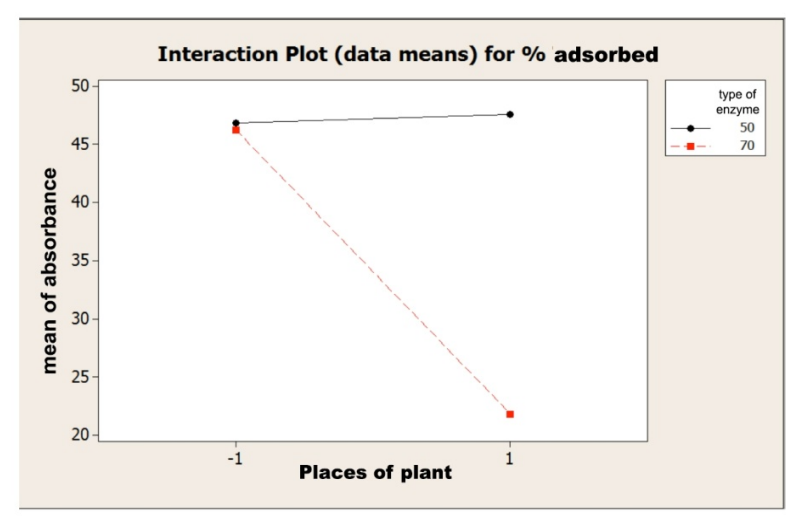

Figure 3. Interaction between types of enzyme vs places of plant

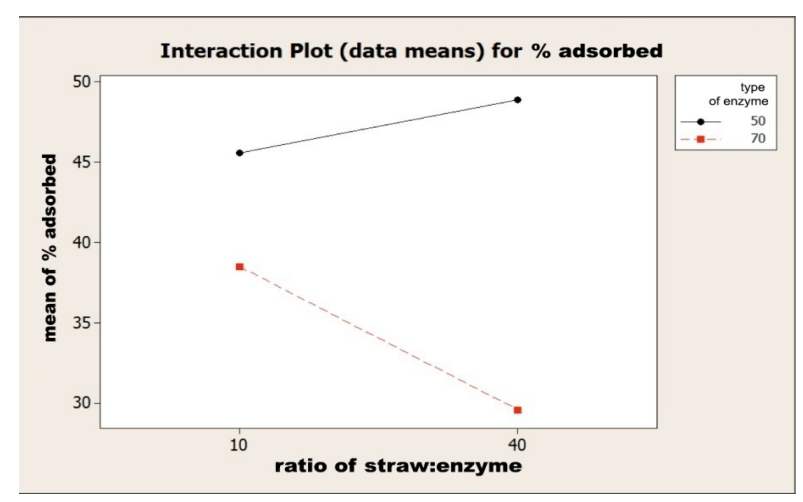

Figure 5. Interaction between types of enzyme vs amount of enzyme

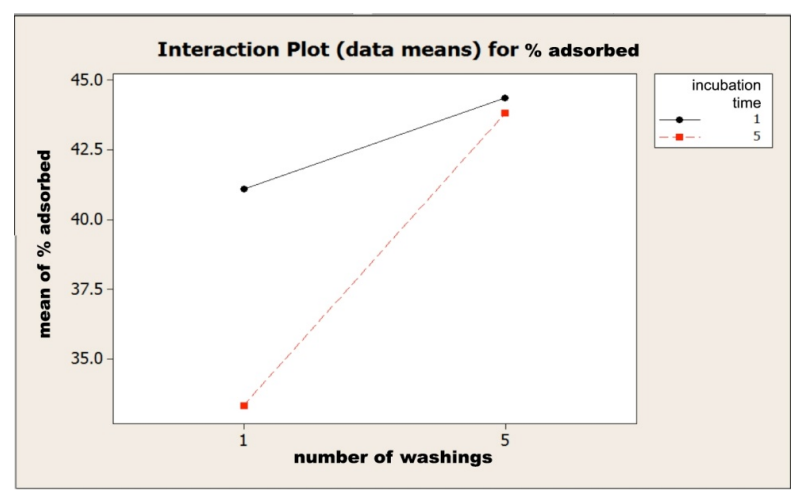

Figure 7. Interaction between time of incubation vs amount of washing

straw: ground. As for the type of washing liquid, both either demineralised water or $\mathrm{Pb}$ solution were the same (difference but not significant).

Interaction between variables also influenced the adsorption of heavy metal, so when one of the interacted variable is changed, it will affect the adsorption process. The adsorption process might 
be a physical or chemical process. In a physical process the heavy metals might be trapped in the cellulose of the straw. Intermolecular hydrogen bonds of the cellulose cause the rigidness of the cellulose and form a woven-like structure. With such a structure, the cellulose can trapp or adsorb the heavy metal in its pores.

The optimum condition of $\mathrm{L}$ - $\alpha$-arabinofuranosidase are either $50^{\circ} \mathrm{C}$ or $70^{\circ} \mathrm{C}$, however, in this research the temperature was set at ambient temperature, in order to simplify the application at larger scale at a later times, because for people especially in the village, more over in a remote area, it will not be convenience to incubate the enzyme at its optimum temperature, as it will be costly and more time consuming.

The composition of straw : enzyme was $1: 2$ and $1: 8$ (by weight). Straw : enzyme $=1: 2$ was used to study whether using a relatively small amount of enzyme would still be able to yield good metal adsorption, while straw : enzyme $=1$ : 8 was chosen to see whether the amount of enzyme would affect the adsorption activity toward heavy metal $(\mathrm{Pb})$.

One and five hours incubation time were chosen to find the shortest incubation time which still would be able to give good results in adsorbing $\mathrm{Pb}$. After incubation period, the straw was washed using demineralised water and $\mathrm{Pb}$ solution (5 ppm). As the research will be continued with an application to clean contaminated water in the village, it will not be convenient for those people to use demineralised water, so a model of contaminated water (i.e. 5 ppm Pb solution) was used to wash the straw in this research.

To find an appropriate amount of washing, 1 and 5 times washing were chosen as a model, while the length or the size of the straw was used in 2 level, ground and half length (or about $30 \mathrm{~cm}$ long), because if the results is about the same, it will be more efficient and less time consuming for the villagers to use the straw without grinding it. However, it was also found that the influence of particle size of straw can be detected only at higher initial concentration of $\mathrm{Pb}$ solution [6].

\section{Conclusion}

The variables that gives the highest respond in this case were enzyme-50, amount of enzyme : straw = $2: 1$ (10 $\mathrm{ml}$ of enzyme for each $5 \mathrm{~g}$ of straw), 1 hour incubation time, amount of washing: $5 \mathrm{x}$ $5 \mathrm{ml}$, place of plant: low land, and size of straw: ground. As for the type of washing liquid, both either demineralised water or $\mathrm{Pb}$ solution were the same (different but not significant). To be more practical and less costly, to make the surface area bigger, the straw can be punched or press or shredded. So grinding is not necessary. However, the variables are still need to be reduced, and the experiment/study will be continued to optimize the reduced variables.

\section{Acknowledgement}

The researchers would like to express their gratitude to The Research Institute and the Faculty of Pharmacy of The University of Surabaya for their financial and laboratory support, to the Faculty of Science and Technology, Airlangga University, for providing the enzyme and the sharing of expertise, and to Prof. L.P.B.M. Janssen for contributing the idea and expertise, especially in completing this article.

\section{References}

1. Sutomo AH, Sarwono RD, Helmi AF. Lead environmental impact to the growth of yogyakarta city children in year 2000. Mediagama. 2001;III(3): 12.

2. Yuliandari E, Triwijati E, Suhardono E. Hakiki. 2000;II(3): 54.

3. Kohar I, Robert M, Churlaud C, Kalombo M. Heavy metals: $\mathrm{Cd}$. $\mathrm{Pb}$ and $\mathrm{Hg}$ in autistic children. Proceeding of International Conference Improving The Quality of Human Life: Multidisciplinary Approach on Strategic Relevance for Urban Issues. JW Marriott Hotel. Surabaya. 2007. 
4. Gardea-Torresdey JL, Hernandez A, Tiemann KJ, Bibb J, Rodriguez O. Adsorption of toxic metal ions from solution by inactivated cells of Larea tridentata (creosote Bush). J. Hazard. Subst. Res. 1998;1(1.34):16.

5. Friedman M, Waiss Jr AC. Mercury uptake by selected agricultural products and by-products. Environ. Scie. And Technol. 1972;6(5): 457-8.

6. Kumar P, Dara SS. Removal of toxic heavy metal ions from wastewaters using modified agricultural waste materials. Water Science and Technology. 1981;13(7).

7. Larsen VJ, Schierup HH. The use of straw for removal of heavy metals from waste water. J. Environ. Qual. 1981;10(2): 188-93.

8. Suemitsu R, Uenishi R, Akashi I, Nakano M. The use of dyestuff-treated rice hulls for removal heavy metals from waste water. J. Appl. Polymer Scie. 1986;31(1): 75-83.

9. Marshall WE, Champagne ET. Agricultural byproducts as adsorbents for metal ions in laboratory prepared solutions and in manufacturing wastewater. J.Environ. Sci. Health Part A. 1995;30(2): 241-61.

10. Soediman S, Kohar I. Penjerapan logam berat timbal $(\mathrm{Pb})$ dan kadmium (Cd) dalam air menggunakan tangkai daun enceng gondok kering. Jurnal Ilmiah Sains dan Teknologi. 2008;3(2).

11. Kohar I, Soediman S, Lystiawati, Yenny. Elimination of cadmium and lead mixture in solution by pretreated rice straw and husk. Unitas (University of Surabaya Research Centre Scientific Bulletin). 2002;10(2): 61-70.

12. Tarley CRT, Arruda MAZ. Biosorption of heavy metals using rice miliing by-products. Characterisation and application for removal of metals from aqueous effluents. Chemosphere. 2004;54(7):987-95.

13. Kohar I, Tiffani, Rokayah, Isadora, Liana, Limdon, de Zeeuw RA. Untreated and pretreated rice straw for the elimination of lead and cadmium from contaminated water. Saintek. 2005;9(1).

14. Kohar I, Fransiscus Y. Adsorption of Cd(II) and $\mathrm{Pb}$ (II) by agricultural waste. Purifikasi. 2007;8(2).

15. Rocha CG, Zaia DAM, da Silva Alfaya RV, da Silva Alfaya AA. Use of rice straw as biosorbent for removal of $\mathrm{Cu}$ (II), Zn (II), Cd (II) and Hg (II) ions in industrial effluents. Journal of Hazardouz Materials. 2009;166(1): 383-8.

16. Soediman S, Kohar I. Adsorption of heavy metals $\mathrm{Pb}, \mathrm{Cd}, \mathrm{Hg}, \mathrm{Ag}, \mathrm{Fe}$, and $\mathrm{Zn}$ from solution by rice straw. Jurnal Purifikasi, Jurnal Teknologi dan Manajemen Lingkungan. 2011;12(3): 9-16.

17. Kohar I, Setyaningrum I. Study on the activity of rice husk and straw pretreated with different concentrations of $\mathrm{NaOH}$ in the elimination of $\mathrm{Cd}$ and $\mathrm{Pb}$. Unitas (University of Surabaya Research Centre Scientific Bulletin). 2002;10(2): 71-83.

18. Kohar I, de Zeeuw RA, Budiono R, Kusumawati L. Review on the use of agricultural waste to adsorb heavy metals from contaminated water. Artocarpus Media Pharmaceutica Indonesiana. 2004;4(1): 39-44.

19. Kohar I, Janssen LPBM, de Zeeuw RA, Tideman J. Particle size experiments on the adsorption of $\mathrm{Pb}$ (II) from polluted water by rice straw. Artocarpus Media Pharmaceutica Indonesiana. 2002;2(1): 29-34.

20. Widianingrum S. Penjerapan $\mathrm{Pb}$ pada sampel buatan menggunakan jerami padi (Oryza sativa L.) dan penghilangan warna filtrat diamati secara visual. Skripsi Fakultas Farmasi, Universitas Surabaya. Surabaya; 2007. 